\title{
METHODOLOGY FOR FAST EVALUATION OF BACILLUS THURINGIENSIS CRYSTAL PROTEIN CONTENT
}

\author{
Lúcia M. Carareto Alves'; Manoel V. F. Lemos ${ }^{2 *}$ \\ ${ }^{1}$ Departamento de Tecnologia, ${ }^{2}$ Departamento de Biologia Aplicada à Agropecuária, Faculdade de Ciências Agrárias e \\ Veterinárias, Universidade Estadual Paulista, Jaboticabal, SP, Brasil
}

Submitted: February 09, 1999; Returned to authors for corrections: June 06, 2000; Approved: September 20, 2000

\begin{abstract}
The development of the production and use of Bacillus thuringiensis in Brazil at a commercial scale faces certain difficulties, among them the establishment of efficient methodologies for the quantitation of toxic products to be commercialized. Presently, the amount of toxin is given in percentage by analyzing the samples total protein content. Such methodology however, does not measure the actual amount of active protein present in the product, since most strains express different endotoxin genes and might even produce b-toxin. Since the various types of toxins exhibit different antigenic characteristics, this work has as objective the utilization of fast immunological techniques to quantify the level of crystal protein. Crystal protein produced by a subspecies of Bacillus thuringiensis var. israelensis was purified by ultracentrifugation and utilized to immunize rabbits and to produce hiperimmune sera. Such sera were latter used to evaluate the level of proteins on commercial bioinsecticide and on laboratory cultures of B. thuringiensis through the immunodot technique. The results were obtained by comparison of data obtained from reactions with known concentrations of crystal protein permitting to evaluate the level of such protein on various materials.
\end{abstract}

Key words: Bacillus thuringiensis, crystal protein, immunological methods

\section{INTRODUCTION}

Bacillus thuringiensis is a Gram-positive spore forming bacterium that produces insecticidal protein(s) called $\beta$ and $\delta$ endotoxin(s).

Since the early 1900's, this bacterium group has received great attention for its use as agricultural and forest insect pest control agent, as well as at the public health area $(2,6)$.

Several commercial formulations were developed, however the use of its subspecies for practical pest control has both advantages and problems. These bacteria produce a toxin that is remarkably safe for humans, domestic animals and nontarget fauna. On the other hand, B. thuringiensis preparations applied to foliage can be washed off by rain and or may be inactivated by sunlight, therefore it is required repeated applications for long term protection against some pest species (2).
The production of $B$. thuringiensis in commercial scale is economically important and in order to develop its production it is necessary available human resources, technology for producing equipments and controls, adequate and cheap raw materials, adapted microorganisms and bioassay facilities. Such procedures might generate a lower production cost and consequently an increase in such product consumption either by farmers or by health program authorities $(2,6)$.

Some difficulties are encountered for the production of $B$. thuringiensis formulations mainly the establishment of standard methods for quantifying the crystal protein content and to determine the potency of $B$. thuringiensis crystal protein preparations since the use of the standardized techniques that measure in ITU/mg of protein are tedious and time consuming.

Unfortunately the necessary analytical methods which can be used to determinate the activity spectrum and the amount of each toxin in $B$. thuringiensis cultivated broths are poorly

\footnotetext{
* Corresponding author. Mailing address: Departamento de Biologia Aplicada à Agropecuária, Faculdade de Ciências Agrárias e Veterinárias, UNESP, Campus de Jaboticabal, CEP 14884-900, Jaboticabal, SP, Brasil. FAX: (+5516) 3202-4275. E-mail: mvictor@ fcav.unesp.br
} 
developed, time consuming and technically difficult to be executed on a regular basis.

Bioassays are routinely used to detect the potency of commercial and experimental B. thuringiensis preparations. They are performed by adding dilutions of the material to be tested to an artificial diet and allowing the susceptible larvae to feed (3). This methodology is laborious and it requires more time to generate data than to complete the fermentation itself.

The knowledge of antigenic differences among the crystal proteins produced by various $B$. thuringiensis strains $(7,8)$ and the use of immunological techniques has increased the development of quantitation methodologies for such proteins.

The existence of distinct antigenic differences among the crystal protein kinds produced by the different $B$. thuringiensis strains and the use of immunological techniques have provided a way to measure the amount of such type of protein using various materials.

An immunoelectrophoretical assay was utilized in some experiments for the detection of crystal protein but this method has the disadvantage of being time consuming (48h) according to Winkler et al. (12) or simply for being a quantitative technique (1).

The ELISA technique used for detection of $B$. thuringiensis crystal protein (9) gives a set of quantitative values with a colorimetric end point either for liquids or powders produced within $4 \mathrm{~h}$ of sampling. It satisfies the criteria for use in a commercial process but it is based on the use of a set of accessories for its usage that it turns out to be expensive. On the other hand Tapp and Stotsky (10) described the use of a method to detect and trace the fate of $B$. thuringiensis var. kurstaki toxins in soil by a dot blot enzyme-linked immunoabsorbent like assay (immunodot) that does not require their extraction and purification, or any piece of equipment specifically designed for that use. Such methodology might be used on quality control on B. thuringiensis crystal protein formulations. The objective of this work has been to adapt the immunodot method to evaluate with specificity and readiness, the amount of free or particulated crystal protein on the different phases of crystal protein production.

\section{MATERIALS AND METHODS}

Bacillus thuringiensis var. israelensis growth conditions Cultures of $B$. thuringiensis var. israelensis were grown in 1 L flasks containing $300 \mathrm{ml}$ of medium (10) with shaking $(250 \mathrm{rpm})$ at $28^{\circ} \mathrm{C}$ until sporulation (usually 5 days).

Crystal protein purification - B. thuringiensis var. israelensis cultures were used for the quantification of crystal protein and latter submitted to ultracentrifugation for its purification following Thomas and Ellar (11). The purified material was lyophilized and kept at $-20^{\circ} \mathrm{C}$ for latter use on rabbit's immunization and immunodot tests.
Hiperimmune sera production - purified crystal protein was used for the production of anti-crystal protein serum (SCP). Rabbits were injected subcutaneously with $1 \mathrm{ml}$ of a $1 \mathrm{mg} / \mathrm{ml}$ suspension of purified crystal protein suspended in sterile water, every week during 8 weeks. Serum antibodies were checked on ear blood samples 5 days after the course of injection. When the reaction titer, by immunodot assay, was $1: 1,000(\mathrm{~V}: \mathrm{V})$ or higher, the animals were bled by cardiac puncture, and the sera separated from the clots, fractionated and stored at $-20^{\circ} \mathrm{C}$.

Immunodot - samples of purified crystal protein with known concentrations and different dilutions of the material, which was used to estimate of the levels of crystal protein, were made by the dilution with $0.85 \% \mathrm{NaCl}(\mathrm{W}: \mathrm{V})$. Rectangles $(11 \mathrm{~cm} \mathrm{X}$ $7 \mathrm{~cm}$ ) of nitrocellulose membranes were cut, rinsed in $\mathrm{NaCl}$ solution (m:V) for 2 minutes and placed in a dot blot apparatus (The Convertible Filtration Manifold System - Gibco/BRL Life Technologies INC). Samples $(10 \mu \mathrm{l})$ of the material refereed above were spotted onto the membranes through the sample wells of the dot blot apparatus and vacuum was applied for 3 to 5 minutes until all samples were applied on the membranes.

If a dot blot apparatus in not available, the protein suspensions can be slowly dotted onto the dry nitrocellulose membranes with the use of a micropipetor.

The dot blot was developed by immunoassay (4) by incubating the membranes for 45 minutes in TBS $(50 \mathrm{mM}$ $\mathrm{NaCl} ; 50 \mathrm{mM}$ Tris- $\mathrm{HCl} \mathrm{pH} 7.5$ ) containing $5 \%$ of nonfat dry milk $(\mathrm{m}: \mathrm{V})$, by washing in TBS, and by incubating for 45 minutes in TBS containing $3 \%$ of nonfat dry milk $(\mathrm{m}: \mathrm{V})$ and the sera anti-crystal protein diluted 1:1,000 (V:V). The membranes were then washed four times (with incubation of 5 minutes) in TBS, after an incubation of 45 minutes in TBS containing goat anti-rabbit immunoglobulin $\mathrm{G}$ conjugated to alkaline phosfatase (Bio-Rad). After four more rinses in TBS, the color was developed by incubating the membranes for 3 minutes in $10 \mathrm{ml}$ of AP buffer $(100 \mathrm{mM} \mathrm{NaCl}, 5 \mathrm{mM} \mathrm{MgCl}$, $100 \mathrm{mM}$ Tris $\mathrm{pH}$ 9.5) containing $66 \mu \mathrm{l}$ of nitro-blue-tetrazolium $(5 \%(\mathrm{~m}: \mathrm{V})$ in $70 \%(\mathrm{~m}: \mathrm{V})$ dimethylformamide) and $33 \mathrm{ml}$ of bromo-chloro-indolyl phosphate $(5 \%(\mathrm{~m}: \mathrm{V})$ in $100 \%$ dimethylformamide $(\mathrm{V}: \mathrm{V}))$. To stop, the reactions were rinsed with TBS containing $20 \mathrm{mM}$ EDTA.

\section{RESULTS AND DISCUSSION}

The Bacillus thuringiensis var. israelensis sporulated samples and two other commercial preparations were analyzed with respect to solid residues and total protein content measured by Hartree (5) and the obtained values are listed on Table 1.

As can be seen, there is a lot of variation on the crystal protein content on the various materials considered (43\%, 5.7\% and $34 \%$, respectively). However, the majority of the proteins 
Table 1. Levels of solid residues and total protein on samples of sporulated B. thuringiensis var. israelensis suspensions and two commercial bioinsecticides (CK and TK).

\begin{tabular}{ccc}
\hline Sampled Material & Solid residue $^{1}(\mathrm{mg} / \mathrm{ml})$ & Protein percent \\
\hline Sporulated culture & 17.4 & 43 \\
CK & 10.4 & 5.7 \\
TK & 212.1 & 34 \\
\hline
\end{tabular}

1 - Measured through lyophilization of $1 \mathrm{ml}$ of sporulated bacterial culture (mean of three samples)

found in these preparations are not crystal protein. Besides the various components of these suspensions (ammonia, nitrite and phosphorous) might have interfered with the dosages and the crystal protein levels discrepant results are not in accordance with the bioassays (data not shown).

The immunodot results for the fast evaluation of crystal protein content are listed on Fig. 1. In such figure, the purified crystal protein known concentrations (lines A and B) and the various dilutions of a sporulated $B$. thuringiensis var. israelensis (line C) were submitted to the immunoenzymatic assays (immunodot) with anti-crystal protein serum (SPC) diluted 1,000 times. As it can be seen the various pure crystal suspensions exhibited different but proportional color intensity for the level of crystal protein, the same occurring for the $B$. thuringiensis var. israelensis dilutions.

On this way it was possible to find the crystal protein concentration on the growth suspensions by comparing the

Figure 1. Immunodot using SPC $(1: 1,000)$ against purified crystal protein $(\mathrm{mg} / \mathrm{ml})$ in different concentrations (lines A and $\mathrm{B})$ and different dilutions $(\mathrm{V}: \mathrm{V})$ of a sporulated culture of B. thuringiensis var. israelensis (line $\mathrm{C}$ ).

\section{I - Dilution scheme of immunodot reaction}

\begin{tabular}{|c|c|c|c|c|c|c|}
\hline & $\mathbf{1}$ & $\mathbf{2}$ & $\mathbf{3}$ & $\mathbf{4}$ & $\mathbf{5}$ & $\mathbf{6}$ \\
\hline $\mathbf{A}$ & 1.000 & 0.500 & 0.250 & 0.120 & 0.060 & 0.030 \\
\hline $\mathbf{B}$ & 0.015 & 0.007 & 0.003 & 0.001 & - & - \\
\hline $\mathbf{C}$ & $1: 20$ & $1: 40$ & $1: 80$ & $1: 160$ & $1: 320$ & $1: 640$ \\
\hline
\end{tabular}

\section{II - Immunodot reaction}

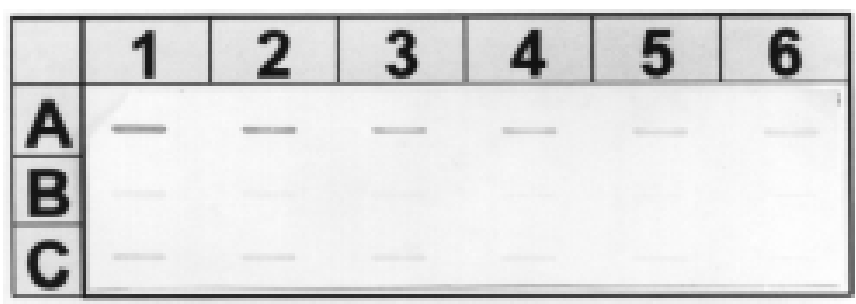

color of its samples with those from known suspensions, that were: 1) the last positive dilution of $B$. thuringiensis var. israelensis is found on the $\mathrm{C} 5$ position which corresponds to the $1: 320(\mathrm{~V}: \mathrm{V})$ dilution; 2$)$ the control concentration with similar color is on position B2 and corresponds to the concentration of $7.8 \mu \mathrm{g} / \mathrm{ml}$. Thus the crystal protein amount present on the cultivation medium is $7.8 \times 320=2.4 \mathrm{mg} / \mathrm{ml}$.

Figure 2. Immunodot using SPC (1:1000) against purified crystal protein $(\mathrm{mg} / \mathrm{ml})$ in different concentrations (column 1) and different dilutions $(\mathrm{V}: \mathrm{V})$ of two commercial $B$. thuringiensis var. israelensis bioinsecticides CK (column 2) and TK (column 3).

\section{I - Dilution scheme of immunodot reaction}

\begin{tabular}{|c|c|c|c|}
\hline A & $\mathbf{1}$ & $\mathbf{2}$ & $\mathbf{3}$ \\
\hline B & 10.0 & $1: 10$ & $1: 80$ \\
\hline C & 5.0 & $1: 20$ & $1: 160$ \\
\hline D & 1.0 & $1: 40$ & $1: 320$ \\
\hline E & 0.5 & $1: 80$ & $1: 640$ \\
\hline F & 0.1 & $1: 160$ & $1: 1,280$ \\
\hline G & 0.05 & $1: 320$ & $1: 2,560$ \\
\hline H & 0.02 & $1: 640$ & $1: 5,120$ \\
\hline I & 0.01 & $1: 1280$ & $1: 10,240$ \\
\hline
\end{tabular}

\section{II - Immunodot reaction}

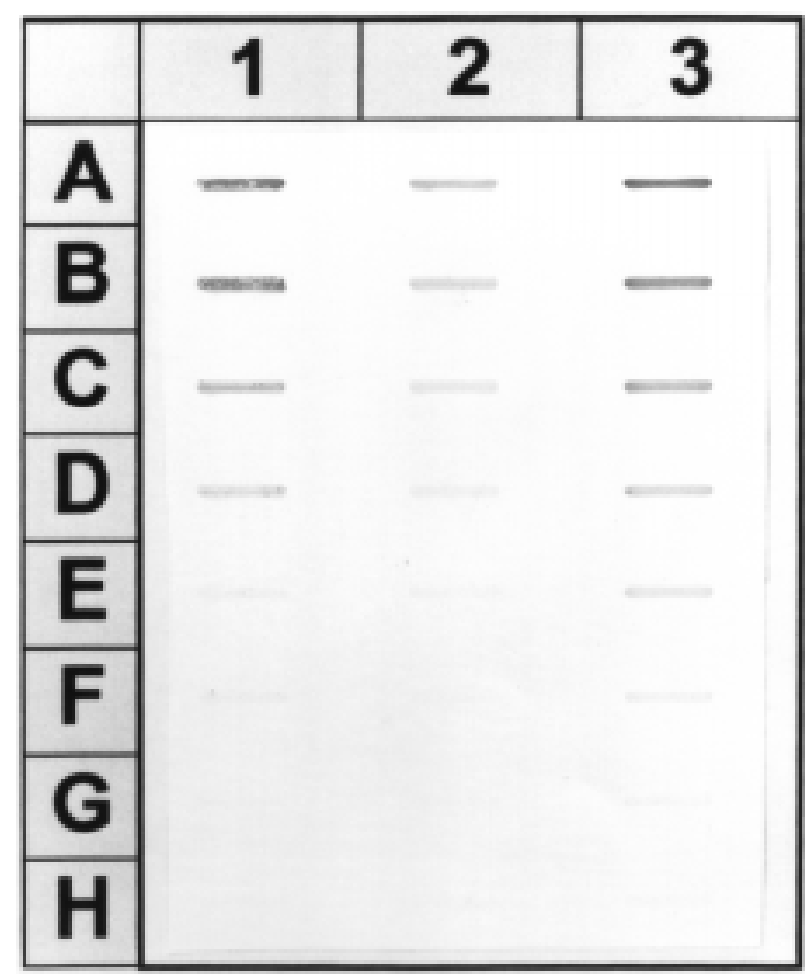


The same evaluation can be developed in order to know the level of crystal protein of commercial products (Fig. 2). At column 1 the immunodot reaction was setup for different concentrations of purified crystal protein and at column 2 and 3 for dilutions of two commercial products made up of $B$. thuringiensis var. israelensis (CK and TK respectively). By comparing the titer found for the two commercial products $(\mathrm{CK}=\mathrm{E} 2=1 / 160$ and $\mathrm{TK}=\mathrm{F} 3=1 / 2560)$ and the color of the control corresponding to such reactions, the concentration of crystal protein for these are: $\mathrm{CK}=8 \mathrm{mg} / \mathrm{ml}(160 \times 0.05)$ and $\mathrm{TK}=256 \mathrm{mg} / \mathrm{ml}(2560 \mathrm{X} 0.1)$.

Since this immunodot reaction detects specifically crystal protein, a color comparison between the controlled amounts with those of unknown quantities presents high degree of confidence, besides being in accordance with biological assays conducted with the same samples (data not shown).

It was possible to conclude that the immunodot technique developed in this paper, is to be recommended as a fast and reliable way to estimate the levels of crystal protein content on different media, besides this such methodology shows important characteristics that fit to the immediate needs of the bioinsecticide commercial producer as well as to those who perform research on the biological control area. Such methodology was shown to have a fast, specific and reliable application for crystal protein evaluation on batch cultures and for commercial products (approximately $3 \mathrm{~h}$ ) and did not require any special apparatus for to be carried out.

Since the necessary material for developing the immunodot reaction is used in very small amounts (purified crystal protein and hiperimmune sera) it can be easily obtained from laboratory and/or commercial sources at low costs.

Besides all the above cited advantages such method can be seen of extreme importance not only for identification purposes and the determination of the crystal protein persistence under environmental conditions but also for the calculations needed for its accurate potency determination.

\section{ACKNOWLEDGMENT}

We are grateful to Dr. Eliana G. M.. Lemos for her critical reading of the manuscript and helpful suggestions and to Eliane C. C. Alves for her excellent technical assistance.

\section{RESUMO}

\section{Metodologia para quantificação rápida de proteína cristal de Bacillus thuringiensis}

O desenvolvimento da produção e uso do Bacillus thuringiensis no Brasil em escala comercial enfrenta certas dificuldades, entre elas o estabelecimento de metodologias para a quantificação de produtos tóxicos a serem comercializados.
Atualmente, a quantidade de toxinas é expressa como porcentagem do total de proteínas presentes em amostras em consideração. Tal metodologia, entretanto, não mede a quantidade real de uma determinada proteína presente em um produto qualquer, além do fato de diferentes linhagens bacterianas possuírem diferentes genes codificadores para endotoxinas e mesmo para b-toxina. Desde que os diferentes tipos de toxinas apresentam diferentes características antigências, este trabalho tem como objetivo a utilização de técnicas imunológicas para quantificar específicamente o conteúdo de proteína cristal presente em diferentes amostras. A proteína cristal produzida pela subespécie $B$. thuringiensis var. israelensis foi purificada por ultracentrifugação e utilizada para imunizar coelhas e produzir soros hiperimunes. Tais soros foram posteriormente usados para avaliar o nível de proteína cristal em bioinseticidas comerciais e em culturas de laboratório desta bactéria utilizando-se a técnica do imunodot. Os resultados foram obtidos por comparação de reações com concentrações conhecidas de proteína cristal permitindo assim avaliar com segurança os níveis desta proteína em várias preparações.

Palavras-chave: Bacillus thuringiensis, proteína cristal, métodos imunológicos

\section{REFERENCES}

1. Andrew, R. E. Jr.; Iandolo, J. J.; Campbell, B.S.; Davidson, L. I.; Bulla L. A Jr. Rocket immunoelectrophoresis of entomocidal parasporal crystal of $B$. thuringiensis var. kustaki. Appl. Environ. Microbiol., 40: 987-990, 1980.

2. Behle, R. W.; McGuire, M. R.; Shasha, B. S. Effects of sunlight and simulated rain on residual activity of Bacillus thuringiensis formulations. J. Economic Entomol. 90: 1560-1566, 1997.

3. Dulmage, H. T.; Boeing, O. P.; Rehnborg, C. S.; Hansen, G.D. A proposed standard bioassay for formulations of B. thuringiensis based on the international unit. J. Invertebr. Pathol. 18: 240-245, 1971.

4. Harlow, E.; Lane, D. Immunoassays. In Antibodies: a Laboratory Manual., New York, Cold Spring Harbor Laboratory, 1988, p. 553-612.

5. Hartree, E. F. Determination of protein, A Modification of the Lowry Method that gives a Linear Photometric response. Anal. Biochem. 46: 47-57, 1972.

6. Kroeger, A.; Dehlinger, U.; Burkhardt, G.; Atehortua, W.; Anaya, H.; Becker, N. Community based dengue control in Columbia: people's knowledge and practice and the potential contribution of the biological larvicide Bti (Bacillus thuringiensis israelensis). Trop. Med. Parasotol. 46: 241-246, 1995.

7. Lynch, M. J.; Baumann, P. Immunological comparisons of crystal protein from strains of Bacillus thuringiensis. J. Invertebr. Pathol. 46: 47-57, 1985.

8. Smith, R.A. Use of crystal serology to differentiate among varieties of Bacillus thuringiensis. J. Invertebr. Pathol. 50: 1-8, 1987.

9. Smith R. A.; Ulrich, J. T. Enzyme-liked immunosorbent assay for quantitative detection of Bacillus thuringiensis crystal protein. Appl. Environ. Microbiol. 45: 586-590, 1983.

10. Tapp, H.; Stotzky, G. Dot blot enzyme-linked immunoabsorbent assay for monitoring the fate of insecticidal toxins from Bacillus thuringiensis in soil. Appl. Environ. Microbiol. 61: 602-609, 1995.

11. Thomas, M. E.; Ellar, D. J. Bacillus thuringiensis var. israelensis crystal delta-endotoxin: effects on insect and mammalian cells in vitro and in vivo. J. Cell Sci. 60: 181-197, 1983.

12. Winkler, V. W.; Hansen, G. D.; Yoder, J. Immunochemical analysis of parasporal crystal digests of Bacillus thuringiensis as an index of insecticidal activity. J. Inverter. Pathol. 18: 378-382, 1971. 